\title{
Two cases of nodular smooth muscle proliferation suspected of primary lung cancer from preoperative images: a case report
}

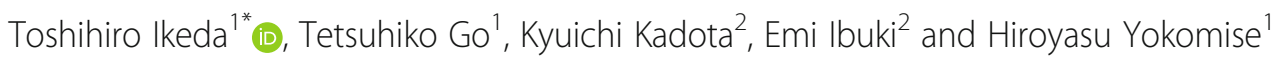

\begin{abstract}
Background: It is difficult to obtain a definitive diagnosis for nodular smooth muscle proliferation (NSMP) before surgery, and a pathological diagnosis is necessary to differentiate it from primary lung cancer. We report two cases of NSMP that were suspected to be primary lung cancer on preoperative images.

Case presentation: Case 1: An 81-year-old man who had undergone right upper lobectomy for lung cancer 2 years earlier was point out a nodular shadow with ground glass opacity (GGO) in the lower right lobe, suggesting a second primary lung cancer by chest computed tomography (CT). A thoracoscopic partial resection of the right lower lobe was performed, and pathological diagnosis was NSMP. The patient was discharged without any problems at 3 days postoperatively.

Case 2: A 72-year-old woman was pointed out a nodular shadow suspected primary lung cancer in the left lower lobe by chest CT. Therefore, thoracoscopic partial resection of the left lower lobe was performed, and pathological diagnosis was NSMP. The patient was discharged without any problems at 5 days postoperatively.

Conclusion: This report demonstrates that NSMP can be distinguished from leiomyoma and hamartoma by imaging features and pathological findings.
\end{abstract}

Keywords: Nodular smooth muscle proliferation, Leiomyoma, Lung benign tumor, Case report

\section{Background}

Benign Lung tumors are rare, ranging from 2 to $5 \%$ of all lung tumors. Smooth muscle lesions originating in the lung represent $2 \%$ of benign lung tumors [1]. Nodular smooth muscle proliferation (NSMP) has been described in detail elsewhere [2]. However, no published reports included in PubMed have examine the radiological and pathological findings of NSMP. Here, we

\footnotetext{
* Correspondence: tike19850916@gmail.com

'Faculty of Medicine, Department of General Thoracic Surgery, Breast and Endocrinological Surgery, Kagawa University, 1750-1 Ikenobe, Kita-gun, Miki-cho, Kagawa 761-0793, Japan

Full list of author information is available at the end of the article
}

report two cases of NSMP that required differentiation from primary lung cancer.

\section{Case presentation \\ Case report: 1}

An 81-year-old man had undergone a right upper lobectomy for right upper lobe lung cancer. Two years postoperatively, chest computed tomography (CT) revealed a nodular shadow with ground glass opacity (GGO) in the lower right lobe, suggesting a second primary lung cancer, although the patient was asymptomatic (Fig. 1). ${ }^{18} \mathrm{~F}-$ fluorodeoxyglucose - positron emission tomography $\left({ }^{18}\right.$ FDG-PET) was not performed preoperatively because

C The Author(s). 2020 Open Access This article is licensed under a Creative Commons Attribution 4.0 International License, which permits use, sharing, adaptation, distribution and reproduction in any medium or format, as long as you give appropriate credit to the original author(s) and the source, provide a link to the Creative Commons licence, and indicate if changes were made. The images or other third party material in this article are included in the article's Creative Commons licence, unless indicated otherwise in a credit line to the material. If material is not included in the article's Creative Commons licence and your intended use is not permitted by statutory regulation or exceeds the permitted use, you will need to obtain permission directly from the copyright holder. To view a copy of this licence, visit http://creativecommons.org/licenses/by/4.0/ The Creative Commons Public Domain Dedication waiver (http://creativecommons.org/publicdomain/zero/1.0/) applies to the data made available in this article, unless otherwise stated in a credit line to the data. 


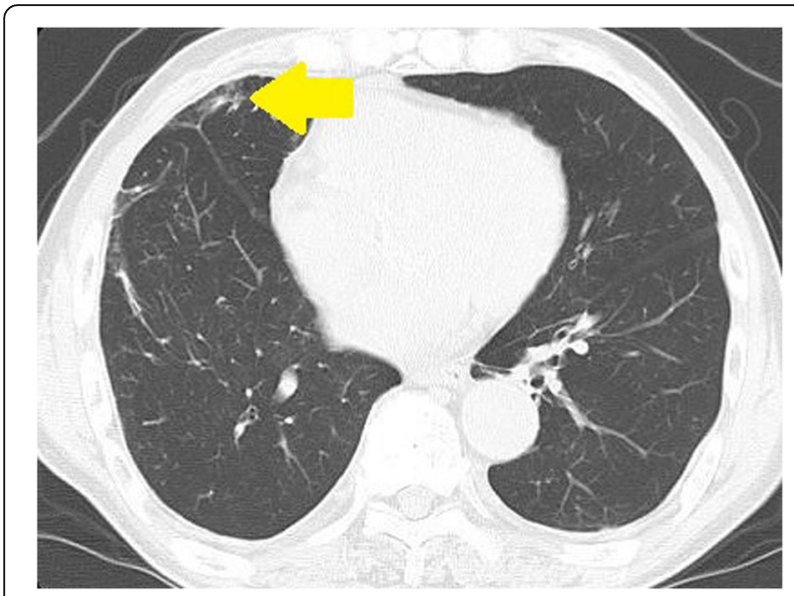

Fig. 1 Chest computed tomography. a 12-mm right lower lobe nodule with ground glass opacity

the lesion was small. The patient consented to a thoracoscopic partial resection of the right lower lobe for diagnosis and treatment. Pathological findings revealed a white-colored, $10-\mathrm{mm}$ nodule with an unclear boundary just below the pleura. Hematoxylin and eosin staining revealed spindle-shaped cells with eosinophilic cytoplasm that had proliferated in a dendritic manner (Fig. 2). Immunohistochemistry revealed desmin and alphasmooth muscle actin positivity. A diagnosis of NSMP was made. No postoperative recurrence has been observed without additional postoperative treatment.

\section{Case report:2}

A 72-year-old woman with no symptoms had a medical checkup, and a subsequent CT revealed a nodular shadow in the left lower lobe (Fig. 3). ${ }^{18}$ FDG-PET was not performed preoperatively because the lesion

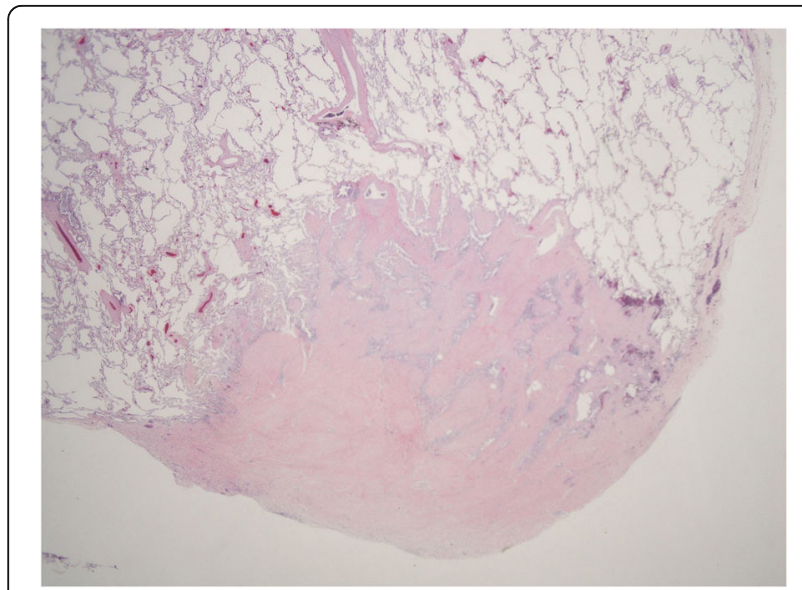

Fig. 2 Pathological findings. Dendritic growth of smooth muscle tissue seen, with an unclear boundary between normal tissue and the lesion (Hematoxylin and Eosin stain $\times 20$ )

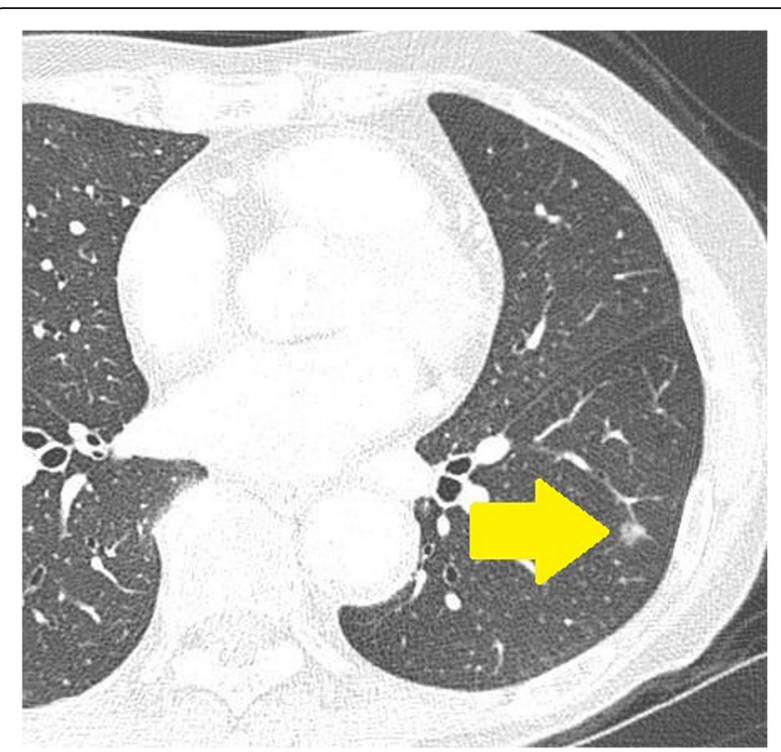

Fig. 3 Chest computed tomography. a 6-mm left lower lobe nodule with ground glass opacity

was small. We suspected a primary lung cancer, and the patient consented to a thoracoscopic partial resection of the left lower lobe for diagnosis and treatment. Pathological findings revealed a $5-\mathrm{mm}$ nodule with an unclear boundary. Hematoxylin and eosin staining revealed collagen fibers, bronchiolar metaplasia, lymphocyte-induced inflammatory cell infiltration, and smooth muscle dendritic growth with foamy histocytes (Fig. 4), Immunohistochemistry revealed desmin and alpha-smooth muscle actin positivity. A diagnosis of NSMP was made. The patient received no postoperative treatment, and no recurrence has been observed.

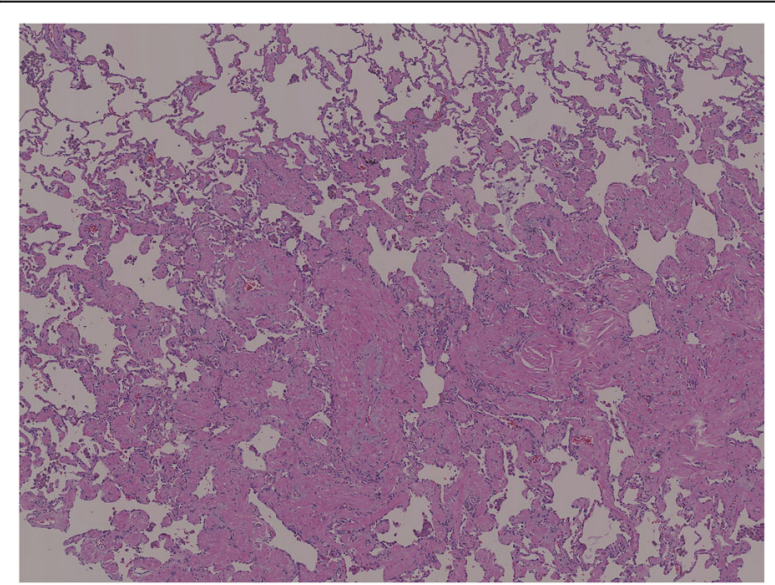

Fig. 4 Pathological findings. Dendritic growth of smooth muscle tissue (Hematoxylin and eosin stain, $\times 20$ ) 


\section{Discussion/conclusion}

The histopathological features of NSMP resemble those of hamartoma and leiomyoma [2], as all three lesions exhibit a proliferation of spindle-shaped cells and smooth muscle upon hematoxylin and eosin staining. Although an immunohistochemical analysis of NSMP reveals desmin and SMA positivity, this is not useful for differentiation from hamartoma or leiomyoma. The difference is that NSMP lesions contain more smooth muscle compared to hamartomas. NSMP also differs from leiomyoma in lesion size. Although no specific definition or standard of NSMP has been established, pathological findings indicate that NSMP exhibits dendritic smooth muscle proliferation, which results in unclear edges. This margin type clearly differs from the smooth margins of leiomyomas and hamartomas. In our cases, the smooth muscle tissue within the lesions appeared dendritic, with an undefined border. In addition, no tissue growth other than smooth muscle tissue was observed in the lesions, which was unlike a hamartoma. These pathological findings led us to diagnose NSMP in both cases. We speculated that the GGO observed around the nodules on preoperative CT was due to the spread of the smooth muscle tissue in a dendritic manner.

A previous report identified fatal pulmonary hypertension as a complication associated with diffuse smooth muscle proliferation on the lungs, which results from pulmonary artery distortion and occlusion by smooth muscle tissue and localized thrombosis [3]. In both our cases, pulmonary hypertension or symptoms of the right heart failure, such as dyspnea, palpitation and edema, were not observed because smooth muscle proliferation was localized, rather than diffuse. However, additional research is needed to determine whether localized smooth muscle proliferation affects pulmonary hypertension. Both patients in this report underwent a partial resection, and neither received postoperative treatment or developed a recurrence. However, some reports of smooth muscle lesions have described malignant transformation [4] and high malignancy [5]. Furthermore, the postoperative follow-up period remains controversial. Further studies are required to understand the treatment and postoperative strategies in managing NSMP. In conclusion, this report demonstrates that NSMP can be distinguished from leiomyoma and hamartoma by imaging features and pathological findings. To our knowledge, this is the first report to review the radiological and pathological findings of NSMP, and it will serve to improve patient outcomes.

\section{Abbreviations}

CT: computed tomography; GGO: ground glass opacity; ${ }^{18} \mathrm{FDG}$-PET: ${ }^{18} \mathrm{~F}$ -

fluorodeoxyglucose - positron emission tomography; NSMP: nodular smooth muscle proliferation

Acknowledgments

Not applicable.
Authors' contributions

Toshihiro Ikeda: Writing of the manuscript. Tetsuhiko Go: Supervision. Kyuichi Kadota: Supervision \& Formal Pathological Diagnosis. Emi Ibuki: Supervision. Hiroyasu Yokomise: Supervision. The author(s) read and approved the final manuscript.

\section{Funding}

Not applicable.

Availability of data and materials

Not applicable.

Ethics approval and consent to participate

The institutional ethics committee approved the clinical study review for case reporting.

Consent for publication

In both cases, the patients consented to the reporting of their case details.

\section{Competing interests}

The authors declare that they have no competing interests.

\section{Author details}

${ }^{1}$ Faculty of Medicine, Department of General Thoracic Surgery, Breast and Endocrinological Surgery, Kagawa University, 1750-1 Ikenobe, Kita-gun, Miki-cho, Kagawa 761-0793, Japan. ${ }^{2}$ Faculty of Medicine, Department of Diagnostic Pathology, Kagawa University, 1750-1, Ikenobe, Miki-cho, Kagawa 761-0793, Japan

Received: 24 March 2020 Accepted: 15 July 2020

Published online: 22 July 2020

References

1. White SH, Ibrahim NB, Forrester-Wood CP, Jeyasingham K. Leiomyomas of the lower respiratory tract. Thorax. 1985:40:306-11.

2. Fraire $A E$, Dail DH. Mesenchymal tumor, part I. In: Tomashefski Jr JF, Cagle PT, Farver CF, Fraire AE, editors. Dail and Hammar's pulmonary pathology, volume II: neoplastic lung disease. 3rd ed. Berlin: Springer; 2008. p. 437-9.

3. Kay JM, Kahana LM, Rihal C. Diffuse smooth muscle proliferation of the lungs with severe pulmonary hypertension. Hum Pathol. 1996;27:969-74.

4. Ogawa M, Hara M, Ozawa Y, Moriyama S, Yano M, Shimizu S, et al. Benign metastasizing leiomyoma of the lung with malignant transformation mimicking mediastinal tumor. Clin Imaging. 2011;35:401-4.

5. Qin BD, Jiao XD, Zang YS. Primary pulmonary leiomyosarcoma: a population-based study. Lung Cancer. 2018;116:67-72.

\section{Publisher's Note}

Springer Nature remains neutral with regard to jurisdictional claims in published maps and institutional affiliations.

Ready to submit your research? Choose BMC and benefit from:

- fast, convenient online submission

- thorough peer review by experienced researchers in your field

- rapid publication on acceptance

- support for research data, including large and complex data types

- gold Open Access which fosters wider collaboration and increased citations

- maximum visibility for your research: over $100 \mathrm{M}$ website views per year

At BMC, research is always in progress.

Learn more biomedcentral.com/submissions 